\title{
PELATIHAN PENCATATAN KEUANGAN BAGI UMKM DI SEKOLAH KEWIRAUSAHAAN BINA AMANAH CORDOVA TANGGERANG
}

\author{
Rina Hartanti \\ Universitas Trisakti, Jakarta, Indonesia \\ e-mail: rinahartanti@trisakti.ac.id \\ Ratna Darasih \\ Universitas Trisakti, Jakarta, Indonesia \\ e-mail: ratna.darasih@trisakti.ac.id \\ Koramen Haulian Sirait \\ Universitas Trisakti, Jakarta, Indonesia \\ e-mail: koramen.sirait@trisakti.ac.id
}

\begin{abstract}
This Community Service Program (PKM) aims to improve the accounting abilities and skills of the training participants whose targets are students who are studying the D-1 program at the Bina Amanah Cordova Entrepreneurship School, to enable them to record financial transactions of Micro, Small and Medium Enterprises (UMKM) business and become successful young UMKM entrepreneurs in his business and is able to make financial reports of the economic transactions of his UMKM business in accordance with SAK-ETAP standards. PKM is held using a persuasive training method by providing practical training on recording economic transactions for UMKM, starting from an explanation of the understanding and accounting process starting from recording economic transactions in journals to the posting process to the general ledger and financial statements, explanation of accounts in Financial Statements, practice of recording financial transactions to the preparation of UMKM financial reports, understanding of ETAP Accounting standards. And also a discussion of financial recording problems that Cordova students still face in the UMKM business where they work or they own. Based on the results of the pre test and post test conducted by the PKM team of the Faculty of Economics and Business - Trisakti University it showed that the abilities and skills of the Bina Amanah Cordova Entrepreneurship School students increased significantly both for the knowledge and skills of SAK-ETAP Standard Theory, Basic Accounting Equations, Transaction Journals, Posting Journals to Books Large, the preparation of the Balance Sheet (Statement of Financial Position), Income Statememt, Changes in Capital Report, Statement of Cash Flow, Cash/Bank Report, with the assessment getting an average value of 60 to 75 indicating the successful implementation of this PKM training has been in accordance with what is expected. It is expected that compared to the results of the pre-test, it is only around the average value of 40 to 55.
\end{abstract}

Keywords- Assets, Equity, Income Statement, Liabilities, Statement of Financial Position 


\section{PENDAHULUAN}

Kemajuan dan keberlangsungan hidup suatu bangsa sangat dipengaruhi oleh pendidikan. Pendidikan dapat membuat masyarakat dari bangsa tersebut berpeluang untuk berkontribusi meningkatkan kualitas hidup bangsa dan Negara nya. Dengan memperoleh pendidikan yang cukup maka setiap individu yang menjadi warga negara suatu bangsa dapat menjadi pribadi yang mandiri secara ekonomi dan tidak bergantung hidup kepada orang lain. Pendidikan dapat memberikan banyak peluang karir dan pekerjaan bagi seseorang, karena semakin seseorang memperoleh pendidikan tinggi maka semakin tinggi peluang orang tersebut dalam memperoleh pekerjaan dengan penghasilan yang tinggi pula.

Akuntansi adalah salah satu bidang pendidikan yang dapat memberikan peluang karir bagi seseorang untuk dapat memperoleh pekerjaan sebagai tenaga akuntan atau memiliki keahlian penunjang pendukung kewirausahawan. Melalui pendidikan akuntansi, dapat membuat seorang individu memiliki kemampuan dan ketrampilan dalam melakukan pencatatan keuangan dari transaksi ekonomi yang ada, terutama individu yang dipersiapkan sebagai usahawan skala UMKM (Usaha Mikro, Kecil dan Menengah). Hikmah, \& Jusmaya, A. (2020) menegaskan dalam pengabdian yang dilakukannya bahwa pembelajaran akutansi keuangan sangat berguna untuk membentuk sikap cermat dalam mengelola keuangan.

UMKM adalah sebuah perusahaan kecil yang dimiliki dan dikelola oleh seseorang atau dimiliki oleh sekelompok kecil orang dengan jumlah kekayaan dan pendapatan tertentu. Usaha Mikro, Kecil dan Menengah (UMKM) memiliki peranan penting dalam perekonomian di Indonesia. Andil UMKM bagi perekonomian Indonesia sudah tidak diragukan lagi. UMKM mempunyai tingkat penyerapan tenaga kerja sekitar $97 \%$ dari seluruh tenaga kerja nasional dan mempunyai kontribusi terhadap produk domestik bruto (PDB) sekitar 57\%. Selain berperan dalam pertumbuhan ekonomi dan penyerapan tenaga kerja, UMKM juga berperan dalam mendistribusikan hasil-hasil pembangunan. UMKM juga telah terbukti tidak terpengaruh terhadap krisis. Ketika krisis menerpa pada periode tahun 1997 - 1998, hanya UMKM yang mampu tetap berdiri kokoh (LPPI dan Bank Indonesia, 2015). Oleh karena itu perlu adanya pemberian pendidikan yang dapat menciptakan usahawan-usahawan muda skala UMKM. Akan tetapi kesadaran masyarakat akan pentingnya pendidikan di Indonesia seringkali menghadapi kendala, seperti kendala ekonomi maupun kendala adanya orang tua yang tidak menyetujui anaknya untuk bersekolah setinggi mungkin. Padahal Pendidikan merupakan suatu proses pembelajaran pengetahuan, keterampilan, dan kebiasaan sekumpulan manusia yang diwariskan dari satu generasi ke generasi selanjutnya melalui pengajaran, pelatihan, dan penelitian (Laipiopa, 2019). Dalam hal ini perlu peran serta masyarakat dalam mensosialisasikan pentingnya pendidikan dalam penciptaan tenaga profesional di bidang kewirausahaan yang memiliki kemampuan dan ketrampilan juga di bidang akuntansi.

Berdirinya Sekolah Kewirausahaan Bina Amanah Cordova memberikan angin segar bagi para lulusan SLTA yang mempunyai kendala ekonomi dapat melanjutkan pendidikannya ke jenjang yang lebih tinggi secara gratis sehingga dapat menjadi usahawan-usahawan muda skala UMKM yang berhasil sekaligus membuka mata para orang tua siswa yang ada di Indonesia bahwa banyak jalan untuk anak-anak mereka dapat menggapai pendidikan tinggi lebih lanjut tampa kwatir dengan biaya pendidikan dan bisa sukses dalam kehidupan masa 
depannya. Dalam hal ini hanya perlu dukungan para orang tua tersebut agar anak-anaknya bisa menempuh pendidikan secara tenang dan kondusif. Para siswa peserta pendidikan program D-1 di Sekolah Kewirausahaan Bina Amanah Cordova merupakan siswa yang sebagian adalah para lulusan SLTA yang belum memiliki usaha dan sebagian lagi siswa lulusan SLTA sudah merintis usaha UMKM dalam skala kecil.

Selama ini para siswa atau selanjutnya disebut sebagai mahasiswa yang menempuh pendidikan program D-1 di Sekolah Kewirausahaan Bina Amanah Cordova memiliki kendala atau permasalahan dalam pengajuan kredit usaha UMKM ke lembaga perbankkan maupun Lembaga keuangan lainnya yaitu pengajuan kredit nya selalu ditolak. Kegagalan para mahasiswa Sekolah Kewirausahaan Bina Amanah Cordova tersebut disebabkan karena ketidakmampuan para siswa tersebut dalam memenuhi persyaratan pemberian kredit berupa penyajian Laporan Keuangan yang benar sesuai dengan Standar SAK-ETAP. Dimana Laporan Keuangan merupakan sumber informasi penting bagi Pihak Lembaga perbankkan atau Lembaga Keuangan dalam mengambil keputusan disetujui atau tidaknya permohonan dari calon debitur yang mengajukan permohonan kredit. Sekolah Kewirausahaan Bina Amanah Cordova Sangat memerlukan tenaga pengajar yang dapat memberikan pengetahuan dan ketrampilan di bidang akuntansi melalui pelatihan pencatatan keuangan Bagi usaha Mikro, Kecil dan Menengah (UMKM). Sebagaimana diketahui bahwa permasalahan yang sering dihadapi oleh usahawan skala UMKM bukan hanya masalah modal kerja saja, tetapi juga masalah kemampuan dan ketrampilan dalam menyusun laporan keuangan usahanya. Selama ini semua transaksi ekonomi usaha UMKM oleh usahawan tersebut hanya sebatas laporan harian kas saja, belum mengerti penyajian laporan keuangan sesuai dengan standar SAK-ETAP.

Oleh karena itu, Program Studi Akuntansi, Fakultas Ekonomi dan Bisnis (FEB) Universitas Trisakti yang bekerjasama dengan Sekolah Kewirausahaan Bina Amanah Cordova menyelenggarakan program Pengabdian Kepada Masyarakat (PKM) dengan judul kegiatan "Pelatihan Pencatatan Keuangan Bagi UMKM di Sekolah Kewirausahaan Bina Amanah Cordova, Tanggerang", yang beralamat di Jl. Japos Raya Kel. Jurang Mangu Barat, Kec. Pondok Aren, Tangerang Selatan, Banten.

Tujuan penyelenggaraan program Pengabdian Kepada Masyarakat (PKM) ini adalah meningkatkan kemampuan dan ketrampilan akuntansi para mahasiswa yang menempuh pendidikan program D-1 di Sekolah Kewirausahaan Bina Amanah Cordova mampu melakukan pencatatan keuangan transaksi ekonomi untuk usaha UMKM. Dengan demikian para siswa tersebut bukan hanya handal sebagai usahawan muda UMKM yang sukses dalam usaha bisnisnya tetapi juga mampu membuat laporan keuangan dari transaksi ekonomi usaha bisnis UMKM yang dimilikinya sekarang maupun di masa yang akan datang.

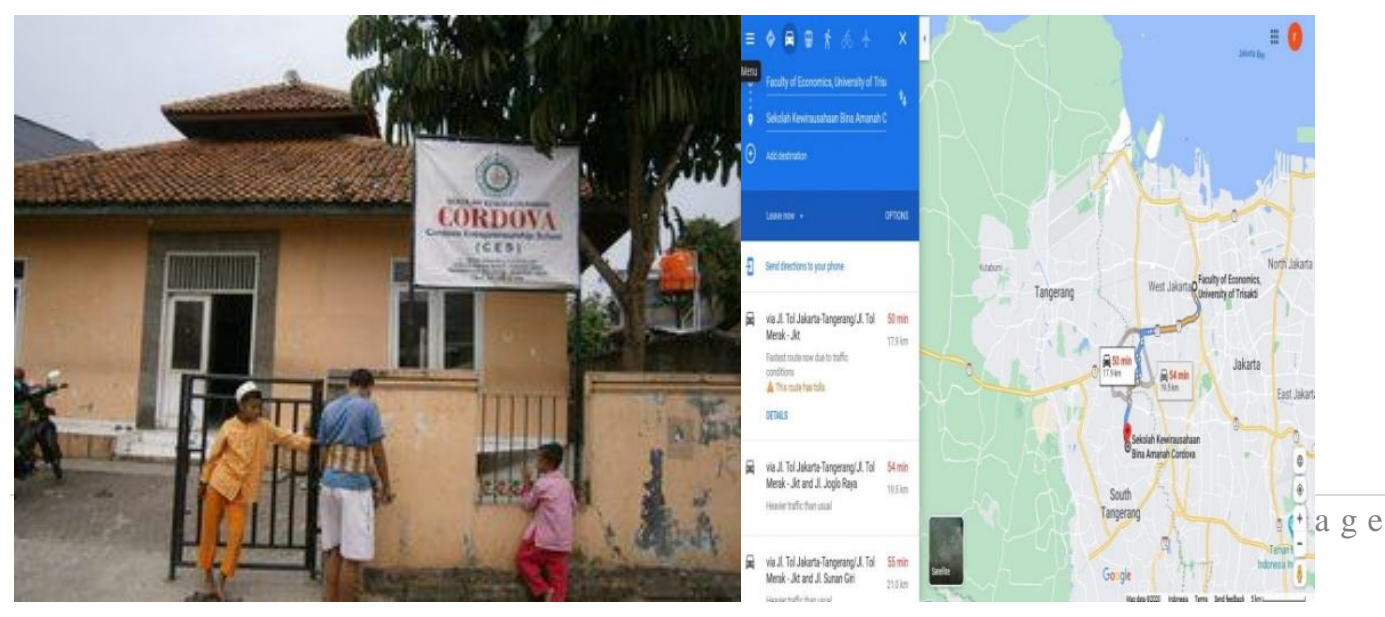




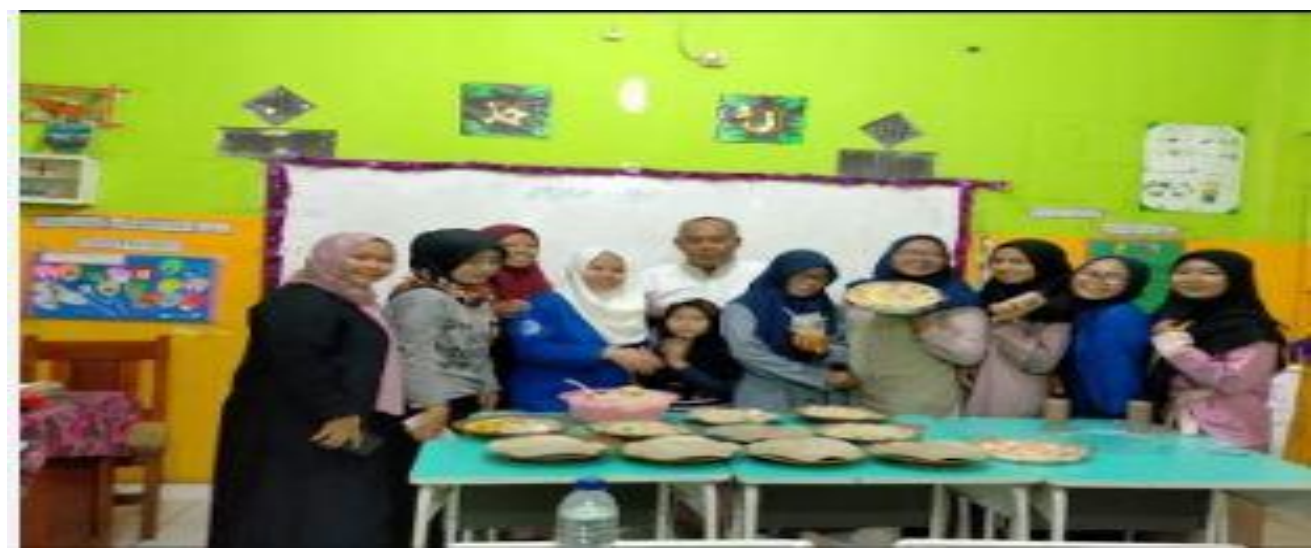

Gambar 2. Sekolah Kewirausahaan Bina Amanah Cordova

\section{METODE}

Sekolah Kewirausahaan Bina Amanah Cordova merupakan lembaga pendidikan SDM Kewirausahaan yang memberikan pendidikan gratis kepada para siswa lulusan SLTA yang mempunyai kendala ekonomi dalam melanjutkan pendidikan ke jenjang pendiidkan yang lebih tinggi. Adapun program pendiidkan yang diberikan adalah program pendidikan D-1 (Diploma 1). Dengan lama pendidikan selama setahun (Yayasan harapan Umat, 2009). Sekolah Kewirausahaan Bina Amanah Cordova Sangat memerlukan tenaga pengajar yang dapat memberikan pengetahuan dan ketrampilan di bidang akuntansi melalui pelatihan pencatatan keuangan Bagi usaha Mikro, Kecil dan Menengah (UMKM). Sebagaimana diketahui bahwa permasalahan yang sering dihadapi oleh usahawan skala UMKM bukan hanya masalah modal kerja saja, tetapi juga masalah kemampuan dan ketrampilan dalam menyusun laporan keuangan usahanya.

Khalayak sasaran peserta kegiatan Pengabdian Kepada Masyarakat ini adalah para mahasiswa baik yang sudah menjadi wirausahawan muda, yang sudah atau belum bekerja dan mungkin masih pemula yang berada dibawah asuhan atau merupakan peserta didik Sekolah Kewirausahaan Bina Amanah Cordova. Peserta didik ini umumnya adalah para lulusan SLTA yang berniat menekuni dunia bisnis (usaha) namun ada hambatan mengenai keuangan dan waktu maupun kendala ekonomi dalam meneruskan pendidikannya ke jenjang yang lebih tinggi. Adalah Sekolah Kewirausahaan Bina Amanah Cordova, sebuah yayasan yang menyelenggarakan pendidikan formal dan sesuai dengan kondisi para pesertanya yang dapat memberikan jalan keluar atas kendala yang dihadapi para lulusan SLTA dalam menempuh pendidikan yang lebih tinggi.

Pengabdian dalam Masyararkat (PKM) ini menggunakan metode pelatihan secara persuasif sebagaimana dapat dilihat pada Gambar 3. Prosedur pelaksanaan PKM ini digambarkan sebagai berikut: 


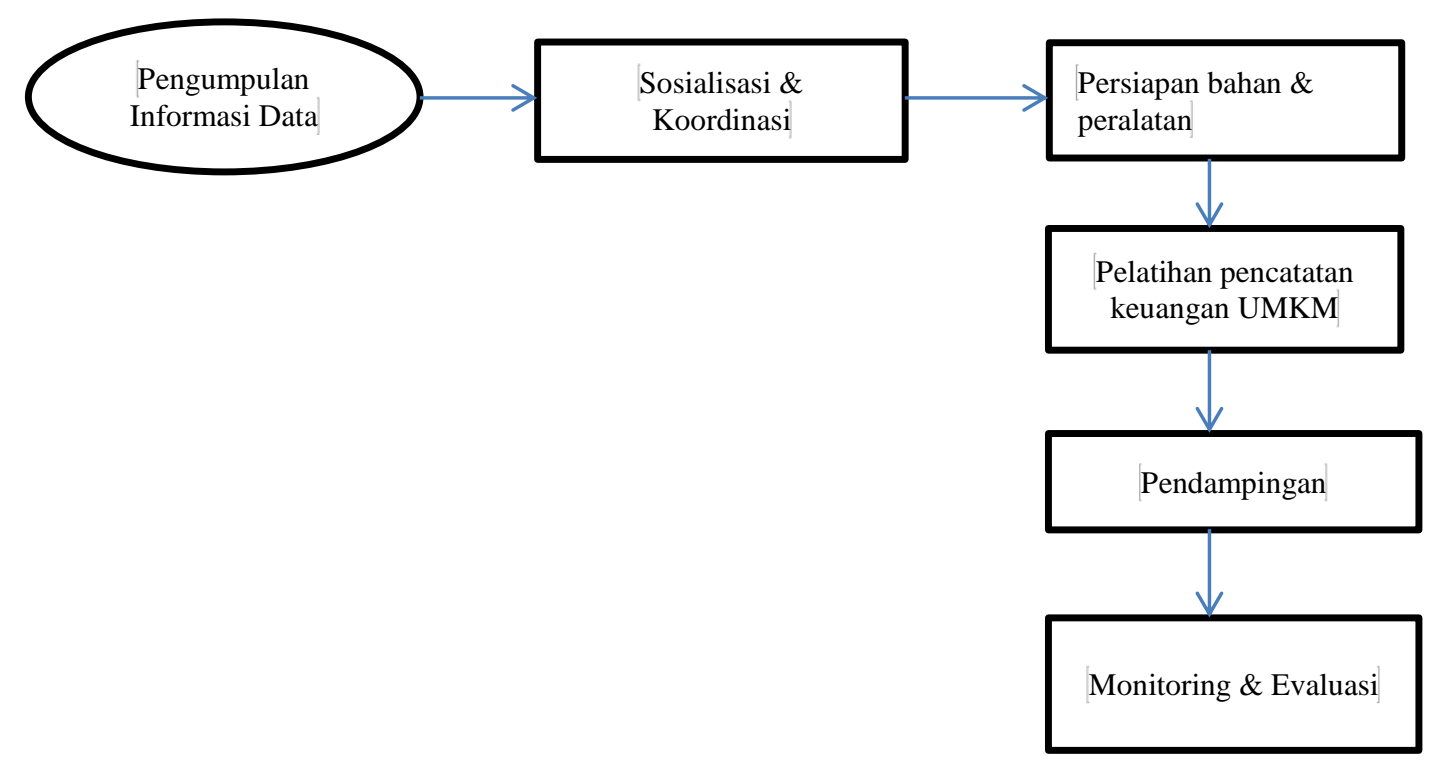

Gambar 3. Prosedur PKM

Pengumpulan informasi data: Pada tanggal 5 Nopember 2020, Tim PKM FEB Trisakti mengumpulkan informasi dan data lapangan tentang Sekolah Kewirausahaan Bina Amanah Cordova baik sejarah maupun tujuan pendidikan, program pendidikan yang diberikan dan informasi lainnya terutama tentang kebutuhan tenaga pengajar yang dapat memberikan pelatihan.

Sosialisasi dan Koordinasi: Pada bulan Desember 2020, Tim PKM FEB Trisakti melakukan sosialisasi dan koordinasi dengan pihak Sekolah Kewirausahaan Bina Amanah Cordova agar bisa mempersiapkan pelaksanaan PKM, tanggal dan waktu pelaksanaan pelatihan pencatatan keuangan bagi UMKM, ketersediaan peralatan untuk menunjang pelatihan. Disamping itu Sosialisasi dan koordinasi juga dilakukan dengan para Mahasiswa Trisakti. Sosialisasi dan Koordinasi ini dilakukan dengan tujuan agar terdapat kesesuaian dalam penyusunan materi PKM dengan kebutuhan pelatihan yang diperlukan dan tahu cara penyampaian materi terbaik kepada para peserta PKM.

Persiapan bahan dan peralatan: Pada bulan Januari 2021 Tim PKM FEB Trisakti mempersiapkan Materi bahan presentasi, kertas kerja akuntansi berupa lembar jurnal, buku besar, dan Laporan perubahan posisi keuangan (Neraca), serta Laporan Laba Rugi.

Pelatihan pencatatan keuangan: Pelaksanaan Pelatihan PKM dilakukan pada tanggal 14 Maret 2021 dimulai jam 8 pagi sampai selesai dan dilakukan secara online (Daring) melalui Zoom meeting dengan tujuan agar terdapat komunikasi dan tatap muka dua arah antara Tim PKM FEB Trisakti dengan para peserta. Dalam hal ini file softcopy Materi PKM dan kertas kerja Akuntansi sudah disampaikan terlebih dahulu kepada para peserta $\mathrm{PKm}$ melalui email maupun WhatsApp Group (WAG) Sekolah Kewirausahaan Bina Amanah Cordova, beberapa hari sebelum tanggal pelaksanaan PKM. Untuk mengetahui keberhasilan pelaksanaan PKM, dilakukan pre test dan post test dengan 
memberikan soal tentang materi yang diberikan dan soal latihan akuntansi kepada peserta PKM, dimana para peserta PKM harus membuat laporan keuangan di kertas kerja akuntansi yang sudah dikirimkan sebelumnya. keberhasilan pelaksanaan PKM ini diperoleh bila para peserta memperoleh nilai 60 atau lebih atas jawaban soal pelatihan di kertas kerja akuntansi.

Pendampingan: Tim PKM Trisakti memberikan pendampingan kepada para peserta PKM sehingga benar-benar mampu dan terampil dalam melakukan pencatatan transaksi ekonomi dan penyusunan Laporan keuangan.

Monitoring dan Evaluasi: Satu bulan setelah pemberian pelatihan, selanjutnya Tim PKM Trisakti melakukan monitoring untuk mengevaluasi apakah pelatihan yang diberikan benar-benar memberikan tambahan pengetahuan maupun ketrampilan pencatatan dan pelaporan transaksi ekonomi dari usaha yang dimiliki atau tempatnya bekerja.

\section{HASIL DAN PEMBAHASAN}

Pendekatan penyelesaian masalah yang dilakukan dalam PKM ini adalah penyampaian materi tentang penjelasan pentingnya pengetahuan cara pencatatan keuangan atas transaksi ekonomi bagi Usaha Mikro, Kecil dan Menengah (UMKM) berdasarkan Standar Akuntansi ETAP. Di samping itu pendekatan masalah yang ada adalah dengan memberikan Pelatihan praktek pencatatan transaksi ekonomi usaha UMKM, mulai dari penjelasan pengertian dan proses akuntansi yang dimulai dari pencatatan transaksi ekonomi di jurnal sampai proses posting ke buku besar dan laporan keuangan, penjelasan Laporan keuangan terdiri dari Laporan apa saja, penjelasan account (akun) dalam Laporan Keuangan, praktek pencatatan transaksi keuangan sampai penyusunan laporan keuangan UMKM, pengertian standar Akuntansi ETAP. Dan Diskusi permasalahahan pencatatan keuangan yang masih dihadapi para siswa Cordova dalam bisnis usaha UMKM tempatnya bekerja atau yang dimilikinya.

Pelaksanaan pelatihan dilakukan dengan zoom meeting pada hari minggu, tanggal 14 maret 2021, mulai jam 08.00 pagi sampai selesai yang merupakan waktu luang peserta pelatihan PKM. Dalam pelaksanaan Pengabdian Kepada Masyarakat ini diikuti oleh 40 mahasiswa dari Sekolah Kewirausahaan Bina Amanah Cordova baik yang belum memiliki usaha maupun yang sudah mulai merintis usaha berskala kecil. Pelatihan PKM ini dilakukan oleh Dosen FEB Trisakti yaitu: Pembicara atau pemberi Materi Pelatihan Pencatatan Keuangan Bagi Usaha Mikro, Kecil dan Menengah (UMKM) adalah Rina Hartanti, Instruktur pelatihan adalah Ratna Darasih dan Koramen Harulian Sirait dibantu oleh 5 mahasiswa FEB Trisakti. Pelaksanaan pelatihan dilakukan dengan Zoom meeting dikarenakan adanya kondisi Pandemi Covid 19 yang melanda Negara Indonesia, dan juga dalam rangka mematuhi Peraturan Pemerintah Indonesia dalam mengatasi masalah Pandemi Covid 19 bahwa pembelajaran harus dilakukan dari rumah saja (Work from home atau WFH) secara online (Daring).

Penjelasan Materi PKM, dimulai dengan penjelasan mengapa perlu pencatatan transaksi keuangan, pengertian akuntansi, dasar persamaan akuntansi, siklus pencatatan keuangan, Output Pencatatan keuangan, Standar 
Akuntansi ETAP untuk UMKM, Contoh soal keuangan dan cara menjawab soal pertanyaan tersebut.

Pencatatan Keuangan diperlukan untuk menentukan hasil usaha, menentukan besarnya Aktiva (harta), Hutang dan Modal, memudahkan pengambilan keputusan penting, Sumber pembuktian tertulis bila terjadi perselisihan, pertanggungan jawab manajemen perusahaan, Memudahkan penghitungan pajak usaha (Weygandt, Kimmel dan Kieso, 2016; Ikatan Akuntan Indonesia. 2018). Transaksi yang dicatat dalam laporan keuangan adalah seluruh transaksi ekonomi usaha yang dapat dinilai dengan uang yang menyebabkan adanya perubahan pada harta, hutang dan modal atau disebut transaki keuangan (Ikatan Akuntan Indonesia. 2018), seperti penyetoran uang tunai atau aktiva lainnya sebagai modal usaha, pengeluaran uang tunai untuk pembelian barang dagangan atau bahan baku usaha, pembayaran biaya listrik, telephone, PAM, gaji pegawai, hutang usaha, pengambilan uang tunai untuk keperluan prive pemilik usaha, dan transaksi keuangan lainnya. Dengan demikian transaksi keuangan adalah aktivitas ekonomi usaha yang harus dicatat (Weygandt, Kimmel dan Kieso, 2016). Pencatatan transaksi keuangan harus didasarkan pada persamaan dasar akuntansi (sisi kanan dan kiri seimbang), dengan memperhatikan akun (transaksi) apa yang terpengaruh atas terjadinya transaksi.

Output akhir dari pencatatan keuangan (proses akuntansi) menuurt Smith \& Skousen (2004) dan Ikatan Akuntan Indonesia (2018) adalah: Laporan Perubahan Posisi Keuangan (Statement of Financial Position) atau Neraca (Balance Sheet), Laporan Laba/ Rugi (Income Statement), Laporan Perubahan Modal atau Ekuitas (Statement of Owners' Equity), Laporan Arus Kas (Statement of Cash Flow), Catatan Laporan Keuangan (Notes of Financial Statement). SAKETAP adalah Standar Akuntansi keuangan untuk entitas tanpa akuntabilitas publik yang menerbitkan Laporan keuangan untuk tujuan umum (general purpose financial statement) bagi pengguna eksternal seperti kreditur, lembaga pemeringkat kredit atau lembaga perbankan (Ikatan Akuntan Indonesia, 2018). Laporan keuangan yang dihasilkan dari proses akuntansi yang menggunakan SAK-ETAP adalah Neraca, Laporan Laba/ Rugi, Laporan Arus Kas, Catatan Laporan Keuangan. Dengan mematuhi SAK-ETAP maka para pengusaha UMKM dapat menyusun Laporan keuangannya sendiri dan dapat diaudit Laporan keuangan tersebut serta mendapatkan opini dari kantor Akuntan Publik.

Dari pertanyaan-pertanyaan yang diajukan oleh para peserta pelatihan PKM, ternyata para mahasiswa Sekolah Kewirausahaan Bina Amanah Cordova baik yang sudah menjadi pegusaha UMKM maupun yang bekerja di sektor UMKM banyak yang tidak mengetahui bahwa penyusunan Laporan keuangan berdasarkan SAK-ETAP merupakan Laporan keuangan yang diminta sebagai persyaratan pengajuan kredit usaha UMKM kepada pihak perbankan atau lembaga keuangan lainnya. Selama ini para peserta tersebut banyak yang hanya membuat Laporan kas harian saja atas transaksi ekonomi usaha UMKM nya, sehingga selalu mendapat penolakan atas pengajuan kredit modal usahanya. Diskusi interaktif dari para peserta pelatihan secara antusias dan keseriusan para 
peserta dalam menjawab praktek soal latihan akuntansi yang diberikan dengan menggunakan kertas kerja akuntansi yang sudah diberikan, dimana hasil penilaiannya memperoleh nilai rata-rata 60 sampai dengan 75 menandakan pelaksanaan keberhasilan pelatihan $\mathrm{PKM}$ ini telah sesuai dengan yang diharapkan yaitu para peserta pelatihan PKM dapat membuat laporan keuangan sendiri yang sesuai dengan SAK-ETAP, sebelumnya hasil pre test nya hanya berkisar rata-rata nilainya 40 sampai 55 . Adapun gambaran hasil nilai pre test dan post test pelatihan PKM ini dapat dilihat pada tabel dibawah ini:

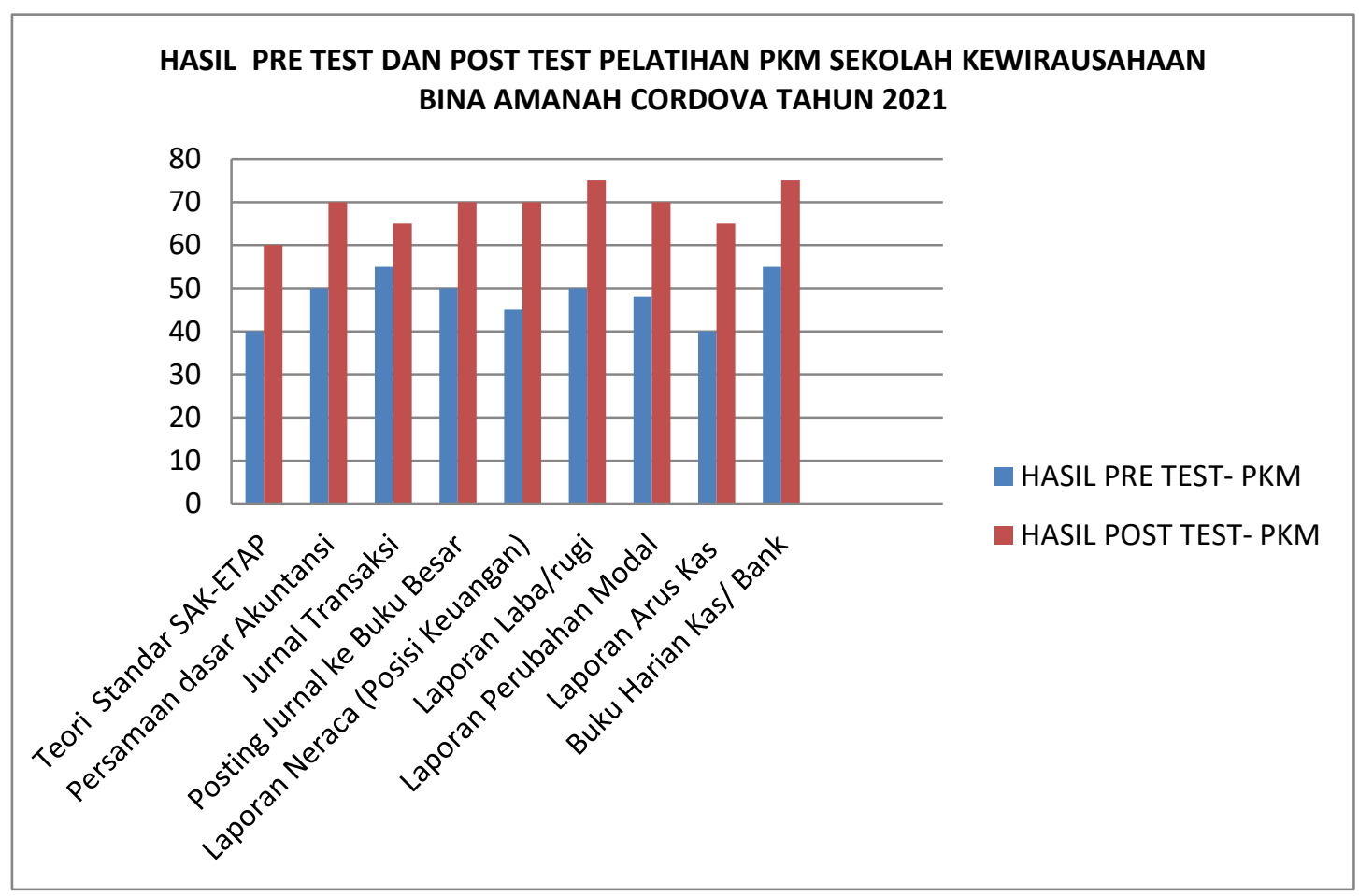

Gambar 4. Diagram Hasil Pre Test dan Post Test Pelatihan PKM

Berdasarkan hasil pre test dan post test yang dilakukan seperti yang dapat dilihat pada tabel 1 diatas, menunjukkan bahwa kemampuan dan keterampilan para mahasiswa Sekolah Kewirausahaan Bina Amanah Cordova meningkat signifikan baik untuk pengetahuan dan keterampilan Teori Standar SAK-ETAP, Persamaan dasar Akuntansi, Jurnal Transaksi, Posting Jurnal ke Buku Besar, penyusunan Laporan Neraca (Posisi Keuangan), Laporan Laba/rugi, Laporan Perubahan Modal, Laporan Arus Kas, Buku Harian Kas/ Bank. Hal ini tentunya memberi nilai tambah dan peluang bagi para mahasiswa Sekolah Kewirausahaan Bina Amanah Cordova memperoleh persetujuan kredit modal usaha yang diajukan ke Lembaga Perbankkan maupun Lembaga keuangan lainnya, karena terpenuhinya persyaratan pembuatan Laporan Keuangan yang benar dan sesuai dengan standar SAK-ETAP yang diperlukan oleh Lembaga Perbankkan maupun Lembaga keuangan lainnya untuk melakukan analisa kinerja usaha UMKM para mahasiswa Sekolah Kewirausahaan Bina Amanah Cordova. Tabel 2 menunjukkan tujuan penyelenggaraan program Pengabdian Kepada Masyarakat (PKM) ini berhasil tercapai. Hasil pelatihan PKM ini 
mendukung hasil penelitian terdahulu dari Rini (2015) yang mengemukakan bahwa Standar Akuntansi Keuangan Entitas Tanpa Akuntabilitas Publik (SAK ETAP) merupakan standar keuangan yang ditetapkan untuk mempermudah UMKM dalam menyusun dan menyajikan laporan keuangan yang lebih informatif dengan tujuan memberikan kemudahan bagi para investor maupun kreditor dalam memberikan bantuan pembiayaan bagi pengusaha UMKM. Sebaliknya bila Laporan keuangan yang disusun tidak berdasarkan standar dan prinsip yang berlaku (SAK ETAP) maka akan dipertanyakan tingkat keandalan dan relevansinya serta akan menyesatkan bagi para pengguna (Fauzi et al, 2018), hal ini dibuktikan sebelum mengikuti pelatihan PKM ini para mahasiswa Sekolah Kewirausahaan Bina Amanah Cordova mengalami kegagalan dalam memperoleh persetujuan kredit modal usaha dari Lembaga Perbankkan maupun Lembaga keuangan lainnya dikarenakan ketidakmampuan dalam penyajian Laporan Keuangan sesuai standar SAK-ETAP.

Tim PKM FEB Trisakti memberikan kesempatan kepada para peserta pelatihan untuk dapat menghubungi TIM PKM FEB Trisakti melalui email atau whatsApp sebagai kegiatan konsultasi apabila menghadapi kendala atau kesulitan dalam pembuatan Laporan keuangan sesuai dengan SAK-ETAP. Dan ini dilakukan sebagai tindakan monitoring TIM PKM FEB Trisakti untuk mengevaluasi apakah pelatihan yang diberikan benar-benar memberikan tambahan pengetahuan maupun ketrampilan pencatatan dan pelaporan transaksi ekonomi dari usaha yang dimiliki atau tempatnya bekerja dalam rangka menyusun Laporan keuangan sesuai SAK-ETAP. Keterbatasan waktu pelatihan yang diberikan pada pelaksanaan PKM ini dan belum semua mahasiswa Sekolah Kewirausahaan Bina Amanah Cordova ikut serta dalam pelatihan progam PKM ini, maka diperlukan kegiatan PKM lanjutan dan berkesinambungan pada Sekolah Kewirausahaan Bina Amanah Cordova.
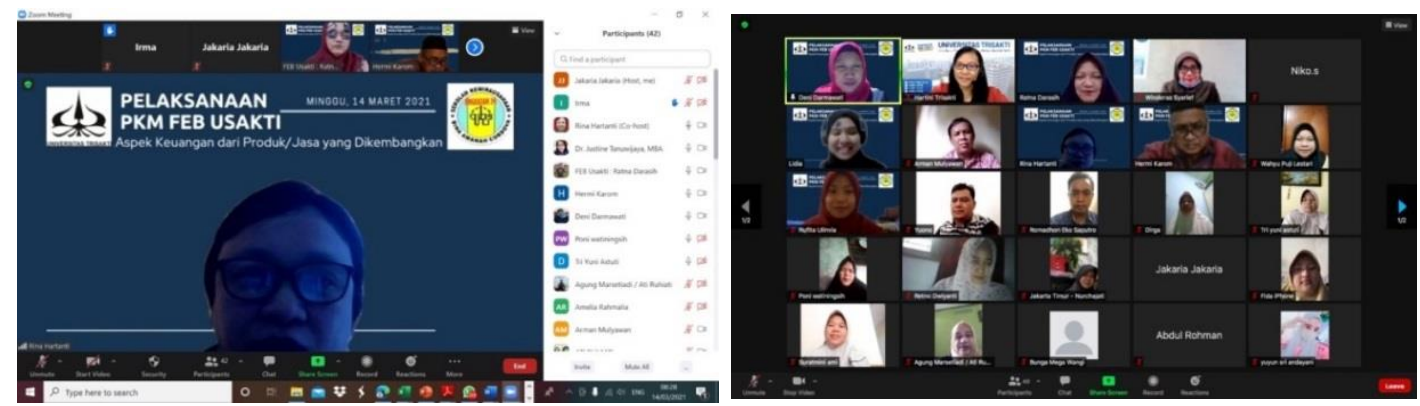

Gambar 5. Kegiatan pelaksanaan pelatihan PKM yang diberikan TIM PKM FEB Trisakti 


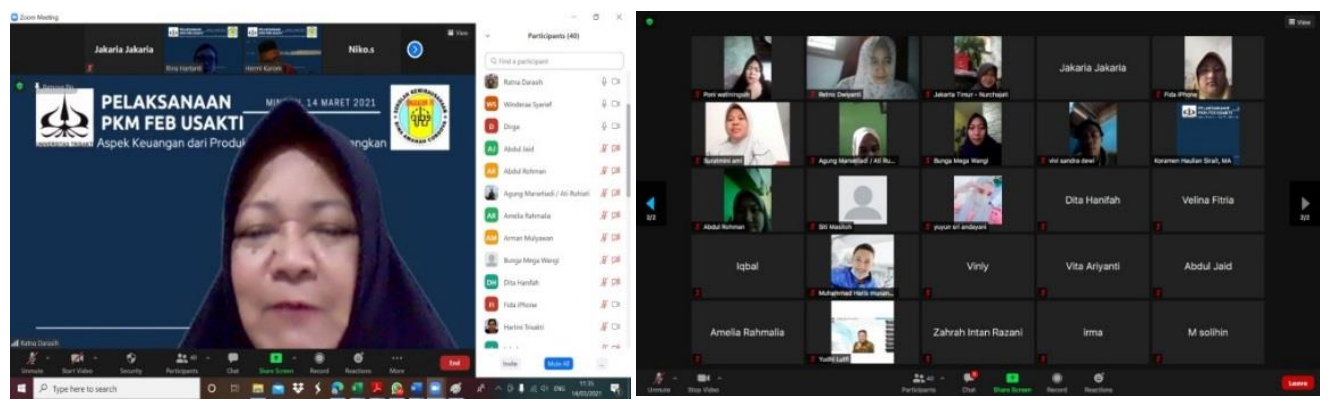

Gambar 6. Kegiatan pelaksanaan pelatihan PKM yang diberikan TIM PKM FEB Trisakti

\section{KESIMPULAN}

Pelaksanaan program Pengabdian Kepada Masyarakat (PKM) bagi Sekolah Kewirausahaan Bina Amanah Cordova bertujuan agar kemampuan dan ketrampilan akuntansi para peserta pelatihan meningkat sehingga dapat melakukan pencatatan transaksi ekonomi dari usaha UMKM yang dimiliki atau tempat bekerjanya dan pada akhirnya mampu menyusun Laporan keuangan sendiri sesuai dengan SAK-ETAP.

Hasil pelaksanaan PKM sesuai dengan yang diharapkan dimana jawaban soal praktek akuntansi yang diisi oleh para peserta pelatihan memperoleh nilai rata-rata 60 sampai 75 . Hal ini menunjukkan pelatihan yang diberikan TIM PKM FEB Universitas Trisakti telah berhasil mencapai tujuan pelaksanaan PKM pada bagi Sekolah Kewirausahaan Bina Amanah Cordova. Adanya keterbatasan waktu pelatihan yang diberikan pada pelaksanaan PKM ini dan belum semua mahasiswa Sekolah Kewirausahaan Bina Amanah Cordova ikut serta dalam pelatihan progam PKM ini, maka diperlukan kegiatan PKM lanjutan dan berkesinambungan pada Sekolah Kewirausahaan Bina Amanah Cordova.

\section{SARAN}

Pelatihan program PKM oleh Tim FEB Universitas Trisakti perlu dilanjutkan lagi secara berkesinambungan dengan ketersediaan waktu yang cukup dan dengan materi yang lebih menarik sehingga bisa memonitoring tingkat kemajuan kemampuan para peserta pelatihan. Hal ini juga membuka kesempatan lagi bagi para mahasiswa bagi Sekolah Kewirausahaan Bina Amanah Cordova yang belum ikut serta pelatihan PKM dapat ikut serta dalam pelatihan PKM berikutnya.

\section{UCAPAN TERIMA KASIH}

Tim PKM FEB Trisakti yang memberikan Pelatihan Pencatatan Keuangan Bagi UMKM di Sekolah Kewirausahaan Bina Amanah Cordova, Tanggerang, yang beralamat di Jl. Japos Raya Kel. Jurang Mangu Barat, Kec. Pondok Aren, Tangerang Selatan ( Banten) mengucapkan banyak terima kasih kepada Fakultas Ekonomi dan Bisnis, Universitas Trisakti-Jakata yang telah memberikan bantuan dan dukungan baik secara moril dan finansial dalam pelaksanaan PKM ini yang telah berjalan dengan baik dan lancar. 


\section{DAFTAR PUSTAKA}

Fauzi, R., Pramiudi, U dan Djanegara, S.M. (2018). Penerapan SAK ETAP Dalam Penyusunan dan Penyajian Laporan Keuangan, Studi Kasus Pada Toko Besi Sumber Baja Mandiri. Jurnal IImiah Akuntansi Kesatuan, Vol.6, No.3, pp. 217- 226.

Lembaga Pengembangan Perbankan Indonesia (LPPI)., \& Bank Indonesia. (2015). Profil Bisnis Usaha Mikro, Kecil Dan Menengah (UMKM). LPPI, Jakarta.

Laipiopa, J. (2019). Pentingnya pendidikan di Indonesia. https://www.kompasiana.com/joiyalaipiopa, diakses tanggal 10 Nopember 2020.

Hikmah, \& Jusmaya, A. (2020). Pembinaan Pengelolaan Keuangan Keluarga Dan Peningkatan Kemampuan Bahasa Inggris Pada Ibu Rumah Tangga Di Perumahan Griya Tahap 1 Batu Aji. Puan Indonesia, 2(1), 45-54. https://doi.org/10.37296/jpi.v2i1.28

Yayasan harapan Umat (2009). Info Kuliah Kewirausahaan Gratis, Bina Amanah. infokuliahgratis.blogspot.com. diakses tanggal 9 Nopember 2020.

Weygandt, j.j., Kieso, E.D., Kimmel, D.P. (2016). Accounting Principles. 12th Edition, Jhon Wiley \& Sons Inc, New York, USA.

Ikatan Akuntan Indonesia. (2018). Standar Akuntansi Keuangan. IAI, Jakarta.

Rini, E.L.F. (2015). Penyusunan Dan Penyajian Laporan Keuangan Berbasis SAK ETAP (Studi Pada UMKM Ekspedisi CV. Manidiri) Periode 2014. Jurnal Kajian IImiah Akuntansi, Vol.4, No. 4, pp.1-10.

Smith \& Skousen (2004). Intermediate Accounting, 8 th Edition, South Western Publishing. 
